\title{
Competing Constructions of Masculinity in Ancient Greece
}

\author{
By Scott Rubarth*
}

Scholars often speak of ancient Greek masculinity and manhood as if there were a single, monolithic, simple conception. I will show that the ancient Greeks, like us today, had competing models or constructions of gender and that what it meant to be a man was different in different contexts. I will focus on three constructions of the masculine gender in ancient (classical and post-classical) Greece: the Athenian civic model, the Spartan martial model, and the Stoic philosophical model. I will focus on how these share certain commonalities, how they differ in significant ways, how each makes sense in terms of larger ideological contexts and needs, and, finally how constructions of masculinities today draw from all three.

\section{Introduction}

What did it mean to be manly or masculine in ancient Greece? There is, of course, a difference between being male and being manly or masculine. The former indicates biological sex; the latter refers to performative gender roles. ${ }^{1}$ The contrast between sex and gender is visible when we say that some men act more manly and others more effeminately. The same applies to women. But what constitutes manliness or masculinity seems to vary, at least in some degree, from culture to culture. The aim of this paper is to understand how the Greeks understood masculinity given the variation of cultural and ideological identity evident in the ancient Greek world of the classical and Hellenistic eras. Scholars often speak of Greek masculinity as if there was a universal ideal of masculinity shared by all Greeks. However, I will show that individual cities, cultures, and philosophies often define masculinity differently and emphasize different aspects of masculine behavior. I argue that masculinity was not a fixed, uniform, monolithic, or homogenous normative concept; manliness was a more fluid concept, full of tensions and inconsistencies. In short, there were different ways for a man to express his maleness in late Classical and early Hellenistic Greece and hence it is better to speak of 'masculinities' and not 'masculinity' when discussing gender in ancient Greece.

There have been numerous studies over the last half-century on the topic of women in Greek antiquity and these studies have significantly advanced our understanding of Hellenic culture and society. Much less work has been done,

${ }^{*}$ George D. and Harriet W. Cornell Scholar in Classical Studies, Department of Philosophy \& Religion; Program in Classical Studies, Rollins College, Winter Park, Florida, USA

${ }^{1}$ West \& Zimmerman, 1987 and Butler, 2001. 
until very recently, on Greek masculinity. ${ }^{1}$ This seems to be because scholars thought that there was not much to say on the topic. Masculinity did not seem to be problematic. However, feminist readings of classical literature and history and recent work in gender studies have taught scholars to ask new questions while re-examining familiar ground. This paper, therefore, is influenced and informed by research in ancient women's studies.

When studying the lives of ancient women, the greatest challenge comes from the scarcity of genuine female voices. Nearly all of the literary remains that have come down from antiquity were written by men. Ancient masculinity scholarship faces the opposite problem: there are too many male voices and the message of masculinity is diffused in the sources. Moreover, we can understand male attitudes to ancient Greek femininity because the male authors and critics saw the feminine gender as problematic and in many cases dangerous. Masculinity, however, was not seen to be problematic; instead it seemed to be intuitive and obvious. Therefore, there is not much direct analysis of the concept in our sources, and consequently, we are frequently forced to read between the lines. When masculinity is discussed, it usually arises when an individual fails to perform masculinity to the standards of the community. In such cases of failed masculinity as well as in exhortations for men to be more manly or less effeminate, we get glimpses of the normative paradigm behind the ideal of masculinity.

Perhaps the most direct and efficient way to demonstrate that masculinity was not a rigid and monolithic normative standard in ancient Greece is to compare different or contrasting ways of life that are moderately well documented from Classical and Hellenistic Greece. I have selected three constructions of ideal manhood from cultures and ideologies in ancient (classical and post-classical) Greece that were recognized as having competing ideals: Athenian, Spartan, and Stoic. The first two are political and cultural identities, while Stoicism represents a philosophical perspective.

During the $5^{\text {th }}$ century, the Athenians and Spartans were the two most powerful political and cultural powers in Greece. They were also seen as contrasting or competing ways of being Greek. Thucydides described Athens as an urban, metropolitan center that maintained its power by its navy and allies and was ruled by a direct and radical democracy. The Athenians were presented as individualistic, capitalistic, pragmatic, greedy, and perhaps ambitious. Athens was the place to go for comfort, progressive ideas, luxury, and wealth. In contrast Sparta was more rural -- a collection of small villages with little interest in civic infrastructure or material culture. Sparta was primarily a land based, military society with little interest in commercial

\footnotetext{
${ }^{1}$ This is especially true on the monograph level; see Berg 2011, p. 99. Discussions of masculinity are often found in more general discussions of Greek sexuality, but such a focus excludes many elements of ancient constructions of manhood. Thomas Van Nortwick's 'Imagining Men: Ideals Masculinity in Ancient Greek Culture' takes a literary and psychological approach to the subject. More useful to this study, at least regarding Athenian masculinity, is Joseph Roisman's 'The Rhetoric of Manhood: Masculinity in the Attic Orators.' Roisman effectively shows that even within Athenian culture of the $5^{\text {th }}$ and $4^{\text {th }}$ centuries BCE tensions and mixed messages abound regarding the proper duties and expectations of manhood.
} 
development. Its value system prioritized the collective over the individual, and discipline and tradition over innovation and self-expression. They lacked coinage making acquisition of wealth more difficult and developed a highly intrusive constitution that became the model for several early utopian political theories.

Politically and socially, Sparta was conservative: slow to act, slow to speak. They feared outsiders and innovation. The state power rested primarily in a counsel of elders (the Gerousia), two hereditary kings, and five annually elected Ephors who represented the assembly of elite warrior-citizens and checked the power of the kings.

Athens, on the other hand, was a radical democracy. Every adult male citizen was expected to vote, serve on juries, and participate directly in the running of the state. Individualism and freethinking were, if not always encouraged, at least tolerated in most instances. In contrast to Sparta, which was wary of tourists and strangers, Athens claimed to be an open society and an exemplar (paradeigma) for all Greece. ${ }^{1}$

The final perspective that we will examine is the ancient Stoics. The Stoa was founded in Athens by Zeno of Citium in the $4^{\text {th }}$ century BCE and remained centered in Athens until the $2^{\text {nd }}$ century BCE. The Stoics bring in a non-statist, philosophical perspective that internalizes masculinity. They serve as a further ideological contrast to both the Athenians and Spartans. The inclusion of Stoic philosophy is also useful since in the early phase of the school Stoicism was primarily an Athenian philosophy. Therefore, if Stoic masculinity varies in a significant way from the standard Athenian construction, which I argue it does, it would imply that the self-fashioning of gender norms was a real option in the $4^{\text {th }}$ and $5^{\text {th }}$ centuries and beyond.

In order to identify the different constructions of masculinity present in Sparta, Athens, and Stoicism, I shall examine four basic topics or central themes associated with the performance of masculinity in order to highlight points of difference. These topics are courage, patriarchy, politics, and sexuality. $^{2}$ I hope to demonstrate that there existed significant differences between expectations and ideals of manhood among Athenians, Spartans, and Stoics to justify speaking of ancient Greek masculinities. ${ }^{3}$

\footnotetext{
${ }^{1}$ Thucydides, 2.37 .1

${ }^{2}$ Several significant methodological challenges face this project. The first deals with scope. It is not unusual for scholars to speak generically of the ancient Spartans and the ancient Stoics. However neither the Spartans nor the Stoics, nor any element of Greek culture is so uniform. The Spartans have undergone much change over the centuries from archaic Greece to Imperial Rome (see Kennell 1995). Likewise the Stoics are anything but a uniform and stable philosophical school. Yet despite the substantial variety in our sources, there remain clear patterns that are worth examining. Hence the focus of my analysis will be on mostly noncontested element of Stoic philosophy and what Ollier calls the 'Le Mirage Spartiate' and Paul Cartledge calls the 'Spartan Myth.'

${ }^{3}$ This study focuses on competing conception of masculinity in the late Classical and Hellenistic age Greece. This means roughly between 490 and to $167 \mathrm{BCE}$, that is roughly between the Persian wars in Greece to the Roman conquest of Greece in the $2^{\text {nd }}$ century BCE. Some of our best sources, especially for the Spartans and Stoics come from later periods, including Roman sources and I will occasionally cite from these sources when they do not
} 


\section{Masculinity and Courage}

Greek conceptions of masculinity are intimately tied to the virtue of courage. The very word that we translate as courage, andreia, comes from the Greek word for a male adult, anêr/andros and can be translated as 'manliness.' Courage is usually used to specify the excellence of bravery and valor, especially on the battlefield. ${ }^{1}$ Hence this is an excellence or virtue not normally applied to women, except by analogy, since women were excluded from military training and activity in all Greek cities. Courage in battle was primarily seen as a male affair.

Given the cultural and linguistic ties between andreia and manliness, we should not be surprised to find that courage is a key ingredient in Athenian, Spartan, and Stoic notions of masculine performance. Nevertheless, how courage fits in, how central it is, and when and in what domains it should be expressed differs between Athenians, Spartans, and Stoics.

Let's begin with the Spartans. Spartan citizens were professional soldiers. From the age of seven they trained exclusively for combat. Young Spartan men lived in camps, trained continuously, and were not permitted by law to participate in farming or trade. Every aspect of their society prepared them for war. Hence courage, as a human excellence took precedence over the other traditional virtues such as wisdom, justice, moderation, and piety. ${ }^{2}$ Courage was so sacrosanct to the Spartans that soldiers who acted in a cowardly manner on the battlefield (so-called 'tremblers') would lose citizen status and suffer such humiliations that suicide or exile would probably be preferable. ${ }^{3}$ Moreover, even the training process itself, the famous agôge required and cultivated a profound sense of courage. Boys undergoing training were treated harshly, given a single cloak to wear for the entire year, no shoes or sandals, limited food rations (in order to cultivate skills in nocturnal thievery), and were frequently required to sleep outside and forbidden any fire or light. Boys were trained and punished by older boys, who could be less restrained than adults. ${ }^{4}$ Discipline in the ranks was brutal and harsh and there are many cases of boys dying from training exercises or from the punishments meted out for even minor infractions. For example, in a famous story a Spartan youth had captured a fox and hid it in his cloak. Not wishing to be caught, which would have brought him shame, the boy continued to hold the fox to his body, never crying out in pain, as the animal began chewing at the child's vital organs. Such

conflict with our knowledge based on earlier evidence and avoid claims that are overtly controversial or problematic.

${ }^{1}$ In Plato's Laches the interlocutors assume the battlefield as a primary locus for andreia. Likewise, when Aristotle discusses andreia, he argues that facing a noble death on the battlefield is the primary meaning of the term (EN III.6, 8).

${ }^{2}$ This is not to suggest that piety or moderation were neglected. Piety in particular was a virtue that Spartans claimed to hold in very high regard. Nevertheless, I argue that andreia was far more central to Spartan identity.

${ }^{3}$ See Ducat 2006 for problems associated with the existence of such "tremblers."

${ }^{4}$ Plutarch tells us that boys administering punishment often had to justify the harshness of the beatings to prevent excessive brutality (Lycourgos 18). 
anecdotes were praised and celebrated, giving us a hint of the significance of physical and mental courage in Spartan society.

Courage was also highly valued by the Athenians and noble feats of courage such as those performed at Marathon and Salamis were deservedly celebrated. However, courage was but one of many virtues for the Athenians and was not as central and all consuming as it was for the Spartans. Athens, like most Greek city-states, did not have a full-time professional army like Sparta. Whereas Athenian teens trained for war as part of their coming-to-age rites, war was always secondary to their regular life. All healthy adult citizens were expected to step up to battle when the city needed them. Those who could afford to keep a horse could enroll as a knight; those with fewer resources might be able to afford a full set of armor and could be hoplites. Finally, the poor who could not afford armor would still fight as skirmishers or rowers in the fleet. But when the fighting ended, each man returned to his day job. ${ }^{1}$

Fear for the Spartans and Athenians, as far as I can tell, was the same thing: an emotive aversion to being harmed, mutilated, or killed in battle. The main difference is that the Spartans cultivated a higher and less compromising standard regarding courage than the Athenians. It was more central to their identity. This difference is evident when we consider Pericles' grand strategy for opposing the Spartans in the Peloponnesian war. The Spartans assumed that when they marched into Attica and began burning farms and ravaging crops that the Athenians would engage them in battle. To their chagrin, the Athenians stayed behind their walls and endured insults and taunts of cowardice from the Spartans. The Athenians were afraid of a direct battle on land and accepted the temporary humiliation in hope of defeating the Spartans by trusting in their long walls, navy, and the resources of their empire in hope of wearing down the Spartans in a war of attrition. To the Spartans, who saw walled cities as signs of effeminacy, the idea of refusing to fight even after being taunted would be unendurable. The Athenians valued courage, but not to such a degree that they would abandon the seemingly prudent strategy of Pericles and swallow their pride.

Since a Spartan's identity and value in culture was linked to his courage, the shame of cowardice was far more profound than it would be with an Athenian. Dropping a shield in battle, which allows one to outrun the heavily armed attacker, was seen as a classic case of cowardice. A Spartan would rather die than return from battle without his shield. Plutarch tells us that Spartan mothers would send their sons off to war with the following admonition: 'Come back with your shield or on it.'

The Athenians, on the other hand, did not face this same degree of pressure. Certainly throwing away one's shield in battle brought shame to Athenian men; soldiers were expected to stand and fight and die for their city when necessary. However, the reality is that the consequences of failure of nerve were less significant in Athenian society than it would be in Sparta. An act of cowardice in war could disqualify a citizen from holding public office

${ }^{1}$ See Plutarch, Agesilaus 26, on the contrast between Spartan professional soldiers and the parttime soldiers of non-Spartan states such as Thebes and Athens. 
and such acts would likely come up in litigation even on unrelated issues. If cowardice on the battlefield is shown to have harmed the city (such as by breaking the line and exposing the army) then the punishment could be severe. However in many cases the pragmatic Athenian might justifiably weigh the cost. Plato's discussion of those who throw away their shields in Laws XII suggests that it was a significant problem in his day among his fellow Athenians.

Further evidence of this point can be seen when we consider the poetry of Archilochus of Thasos, a $7^{\text {th }}$ century lyric poet from Northern Greece. In a well-known poem Archilochus sang:

Some barbarian is waving my shield, since I was obliged to

Leave that perfectly good piece of equipment behind

Under a bush. But I got away, so what does it matter?

Let the shield go; I can buy another one equally good. ${ }^{1}$

An Athenian could smile at such a poem and understand the merits of such pragmatism. In contrast a Spartan would see the poem as shameless and subversive. ${ }^{2}$ Tyrtaeus of Sparta, a contemporary of Archilochus, better captures Spartan expectations and ideals:

Here is courage, mankind's finest possession, here is

The noblest prize that a young man can endeavor to win

And it is a good thing his city and all the people share with him

When a man plants his feet and stands in the foremost spears

Relentlessly, all thought of foul flight completely forgotten.... ${ }^{3}$

Such a high sense of shame and commitment to courage rests behind the famous story of Leonidas and his three hundred Spartans who did not abandon the pass at Thermopylae even though it meant certain death.

In contrast to the Spartans and Athenians, the Stoic philosophers looked at courage in a very different way. According to the Stoics, all the virtues are forms of knowledge. Courage is 'knowledge of what is terrible, what is not, and what is neither." ${ }^{4}$ This needs some background explanation to make sense. Stoic ethical theory rests on a correct understanding of what is good, what is bad, and what is indifferent. Only virtues, which are forms of knowledge, are good; only vice or ignorance is bad; everything else, wealth, reputation, health, family, property, and even life itself is of indifferent value. In other words, good and evil belong exclusively to moral responses. Everything else (externals) have no intrinsic value since all externals can be used equally for

\footnotetext{
${ }^{1}$ Lattimore 1960, Archilochus fragment 3.

${ }^{2}$ Archilochus' poetry was celebrated in Athens. There is even a late tradition that claims that Archilochus was denied hospitality in Sparta due to the moral content of his poetry (Valerius Maximus 6.3).

${ }^{3}$ Lattimore 1960, Tyrtaeus fragment 1.

${ }^{4}$ Arius Didymus, Epitome, 5b1.21ff = SVF $3.262=\mathrm{LS} 61 \mathrm{H}$.
} 
good or evil. So how does this apply to courage? Courage is the knowledge that life, death, suffering, mutilation, and pain are not evil since they harm only the body. True evil is harming one's own soul by ignorantly choosing to do wrong. The Stoic knows that death is in the cards for everyone. So the real question is not how to avoid death, but how to die nobly. That is what is up to us and what is in our power. Courage therefore does not come from physical training but from having a correct philosophical understanding of how the world works and what belongs to human choice. Thus Stoics don't face fear; they understand the true nature of what is terrible and what is not.

\section{Masculinity and Patriarchy}

Courage, however, is only one way for a Greek male to perform masculinity. Andreia does not exhaust the concept. To be a man also implies being the head of a household. While being a man is first and foremost being an effective and brave soldier in Sparta, soldiering was less central to the daily lives of most Athenian men or Stoic philosophers. In Greece wars tended to be seasonal. So how does one perform masculinity when not at war? In Athens being the head of a household or oikos is one of the main ways to demonstrate male power. The Athenian head of a household was the kurios (master, lord). The kurios had absolute control over his household; the state had little to say regarding how he treated his wife and children, managed his slaves, or spent his free time. Thus the manly ideal in Athens included marriage, fatherhood, estate management, and mastery over slaves. Those who failed to marry and produce children, or who squandered their inheritance, or failed to control their slaves also failed at being a man. Moreover, those who infringed on the household of another, particularly on the women of the household were seen as attacking the kurios' manhood. To be cuckolded is to be unmanned. Hence the most severe penalties were laid out against adulterers. If caught in the act, a husband was entitled to kill the adulterer. If found out later, the punishment could result in heavy fines and corporal punishment, including the shaving of the genitals and the sodomizing of the offender with a large radish or root. ${ }^{1}$

In contrast, the household played a much less significant role in Spartan masculinity. Since Spartan youths leave the home at the age of seven and live and eat in the military barracks, their real home is the army and their real family is the members of their common messes. Spartan men do not run the homes -- Spartan wives do with the help of helot serfs. Spartan women likewise are relatively autonomous at home, in contrast with Athenian women who were prevented from making important domestic decisions. Likewise, in Sparta women were the primary beneficiaries of the resources of the estate and the primary consumers of luxury goods. ${ }^{2}$

\footnotetext{
${ }^{1}$ Allen 2003, p. 214.

${ }^{2}$ See Pomeroy 2002 for the most extensive discussion of the lives and roles of women in Spartan society.
} 
If we can trust Plutarch, Spartan marriage procedures highlight the disconnection between Spartan men and their home estates. Plutarch reports that Spartan men did not marry until the age of thirty. At that time a marriage was arranged as a sort of mock rape. With the help of friends the woman was captured by the man, taken home, and then marriage was consummated in the dark. Afterwards, the new husband would return to camp before daybreak, leaving all domestic responsibilities with his bride in the daylight hours.

Paternal responsibilities were also diminished in Sparta. Spartan boys were not raised and disciplined, after the age of seven, by their fathers but by various Spartan military officials and older boys. When they became teens they were guided by older males in pederastic or mentor relationships. In Spartan culture all adult citizen males oversaw the discipline of children. Thus fatherhood entailed primarily a biological role and not a nurturing or pedagogical role. Indeed other boys and older young men were most likely the primary influences on the developing youth.

Finally, the decision to raise children was governed by the Spartan collective and not the individual. In Athens, when a child was born, it was the father who decided if the child was to be raised or exposed. In contrast, in Sparta it was the Gerousia who inspected the child and decided whether the child was to live. If the infant passed muster, the child was raised, if not, the child was exposed irrespective of the biological father's wishes. This means that the family was seen more as a patriotic duty and less as a way to stake one's claim in the future.

We see something similar in the case of marriage. In Athens, the primary aim of marriage was the maintenance of the family bloodline, thereby encouraging the continuance of worship or reverence of ancestors and instilling hope that the individual might not lose his entire identity after death. In Sparta, by contrast, the primary focus was to produce future warriors for the state. Ancestor cult and the cult of the individual was minimized resulting in the recurring problem of oliganthropia, that is, a shortage of Spartan citizens that eventually contributed to the decline of Spartan society.

\section{Masculinity and Political Participation}

In addition to defining their masculinity as being masters of their household, in Athens an essential part of masculine identity was to be actively involved in the running of the state. This entailed more than just voting. An Athenian male was expected to serve on different committees, act on juries, join political associations, keep informed, and argue about politics constantly. The most powerful men, or as Aristophanes says in Plato's Symposium, 'the most manly men,' became politicians which means using rhetoric for political ends. In this domain, speech and critical thought became essential since political rhetoric was competitive. Not only could one beat an opponent in a debate or civil lawsuit, a skilled speaker could 'unman' his enemies through the clever use of vitriolic and abusive speech. 
Again, the contrast with the Spartans is pointed. The Spartans were famously laconic or short on speech. In fact, the term "laconic" comes from the name of the homeland of the Spartans, Laconia. According to legend, when Sparta initiated its radical military reforms, they also drove out intellectuals and artists (xenelasiai). ${ }^{1}$ Athens, on the other hand, drew artists and intellectuals from all over the Greek world and often employed them as teachers for the sons of affluent citizens. This created a well-documented cultural crisis that pertains directly to our discussion of masculinity. Conservatives feared the new education and contrasted it with nostalgia for the more Homeric virtues of tough-minded courage and the commitment to the oikos or household. In Aristophanes' comedy The Clouds we see the two forms of education contrasted in parody. While the masculinity of rhetoric and sophistry gave an individual political power and control, it appeared to do so at the cost of a strong and healthy body and a traditional commitment to the family. Therefore Aristophanes presents the new students of rhetoric as being pale, thin, with poor posture, drenched in perfume, and exhausted by continual illicit sex. The progressive voice in the argument presents the traditional forms of masculinity as old-fashioned, impotent, and powerless in the cutthroat arena of the law courts and assembly.

The Stoics again present an alternative to either extreme. The Stoic also cultivated the intellect as a primary end but opposed the use of the mind for personal aggrandizement or enrichment. The point of thinking is to learn how the world works so one can live in agreement with it and not be vulnerable to externals. Once one truly understands that externals such as wealth, health, family, political position, and reputation are not true goods, since such things can be used for good or evil and dependencies on such things that are outside of our control makes one vulnerable to the vicissitudes of nature, one became liberated and fully realized as a human being. Moreover, since the Stoic held that all the virtues are interconnected and unified and that it is impossible to possess any virtue without possessing all virtues, the result is that the Stoic cultivated virtues that both harden the body and sharpen the mind.

Stoic masculinity shares many similarities with the Spartan ideal and many significant differences as well. First, both Spartans and Stoics saw life as a continuing act of training. Next, they agreed that the object of life's energies and ambitions are not external goods such as property, family, wealth, or even reputation. The goal is to transform the person, for the Spartan into the best possible soldier, for the Stoic, into the sage.

The Athenian of course also (ideally) cultivated virtues. Athenians of military age certainly trained for warfare and prominent Athenian politicians trained in rhetoric. To head a household effectively one needed to develop the skills and expertise associated with one's given profession. However, for the Athenian these excellences tended to be valued primarily for the sake of externals such as wealth, security, respect, and status in society. In short the Stoic and Spartan trained to be a certain sort of individual. The Athenian trained in order to have certain benefits.

${ }^{1}$ Powell 2002, p. 158. 


\section{Masculinity and Sexuality}

The final element of masculinity that I will examine is that of sexuality. In the above discussion of the role of masculinity in war, family, and politics the focus was positive, on ways to be manly. However, another way to define masculinity is to identify what it is not. The masculine is that which is not feminine. Much of the rhetorical discourse and vituperative literature relies heavily on identifying perceived female characteristics in men as a form of attack, insult, or moral admonition. The key theoretical move underlying the moralizing of gender discourse was the idea that men and women represent opposite impulses. Consider the following table of essentializing oppositions:

\begin{tabular}{|c|c|}
\hline Active & Passive \\
\hline Hard & Soft \\
\hline Courageous & Fearful \\
\hline Hairy & Smooth \\
\hline Political & Domestic \\
\hline Law & Nature \\
\hline Outside & Inside \\
\hline Producer & Spender \\
\hline Powerful & Weak \\
\hline Rational & Emotional \\
\hline Consumer of beauty & Object of beauty \\
\hline Hunter & Prey \\
\hline Attacker & Victim \\
\hline Lover & Beloved \\
\hline
\end{tabular}

Insofar as a man's behavior is inclined to the left side of the table, he was believed to be more masculine. If his actions inclined to the right, he was considered effeminate or womanly. This essentialist paradigm especially influenced the Athenians and (to a lesser extent) the Stoics. ${ }^{1}$ For the Stoics, living in accord with nature was the aim of life; hence they expected that gender and sexuality should line up. This way of thinking has been historically very influential and the source of much oppression under the guise of natural law theory. The Stoics did not understand the difference between gender and sex sufficiently to grasp that nature in fact does not always match the cognitive state of gender with the biological apparatus in sexuality. Hence, their argument when applied to gender issues seems to be ill founded.

The Spartans, on the other hand, faced a different difficulty. One of the biggest differences between Athens and Sparta was the status of women. As mentioned above, Athenian women were supposed to stay at home, barefoot (or in delicate slippers), pregnant, out of the public eye. They spent much of

\footnotetext{
${ }^{1}$ The Stoics seemed to have held that women and men were equal in terms of rational and moral potential. However, when it came to exercising reason and virtue, the Stoics encouraged women to shine in traditional roles consistent with the essentialized categories above. See Asmis 1996 and Nussbaum 2002.
} 
their time sequestered in the women's quarters in the home, did not exercise, were not allowed to inherit or do business, and were not formally educated.

In Sparta women lived very different lives. They were relatively autonomous since the men spent so much time in military training. Nor were they merely passive trophy wives. Aristotle claimed that Sparta was a gynecocracy, a state ruled by women. He added that women in his age owned two-fifths of Spartan land. ${ }^{1}$ Even if Aristotle is exaggerating, which is likely, it is widely accepted that Spartan women were allowed to acquire wealth, inherit property, were educated, and even trained physically, possibly even in the nude like their male counter-parts. In short, the polar opposition assumed above does not work so well when women are allowed to flourish and develop themselves like the men. Spartan women were healthy, fit, active, hard, intelligent, productive, and often powerful, rich, and independent. While Spartan men could still speak of manliness and womanliness in normative terms given the primacy of the virtue of andreia in their society, a radical contrast was not as effective as it was for the more essentialist Stoics and Athenians.

\section{Conclusion}

Scholars often speak of ancient Greek masculinity and manhood as if there was a single, monolithic, simple conception. In this paper I have tried to show that masculinity in fact had different faces and points of focus. I have addressed only three possible ways to construct masculinity. There were likely others as well. In short, the ancient Greeks, like us today, had competing and heterogeneous models or constructions of gender and what it meant to be a man or perform masculinity could be different in different contexts. ${ }^{2}$

\section{References}

Allen, D. S. (2003). The World of Prometheus: The Politics of Punishing in Democratic Athens, Princeton University Press.

Asmis, E. (1996). "The Stoics on Women." Feminism and Ancient Philosophy: 68-93.

Berg, H. (2011). Masculinities in Early Hellenistic Athens. What is Masculinity?: Historical Dynamics from Antiquity to the Contemporary World. S. Brady and J. H. Arnold, Palgrave Macmillan.

Butler, J. (2011). Bodies That Matter: On the Discursive Limits of Sex, Taylor \& Francis.

Cartledge, P. (2003). The Spartans: the world of the warrior-heroes of ancient Greece, from utopia to crisis and collapse, Overlook Press.

\footnotetext{
${ }^{1}$ Aristotle, Politics 2, 1270a.; see Figueira 2010.

${ }^{2}$ I would like to thank Kenny Morrell, Gregory Nagy, Christos Giannopoulos, Katerina Schinochoriti, and the staff of Harvard University's Center for Hellenic Studies in Greece for generously hosting me in Nafplio and providing office space and resources as I completed the research for this article. I also wish to thank Rollins College for providing financial support for this project through the Jack B. Critchfield Research Grant.
} 
Cartledge, P. A. and A. Spawforth (2002). Hellenistic and Roman Sparta: A Tale of Two Cities, New York.

Ducat, J. (2006). The Spartan tremblers. Sparta and War. S. Hodkinson, A. Powell and J. Christien, The Classical Press of Wales: 1-55.

Figueira, T. J. (2010). Gynecocracy: how women policed masculine behavior in Archaic and Classical Sparta. Sparta: The Body Politic. A. Powell and S. Hodkinson. Wales, The Classical Press of Wales.

Kennell, N. M. (1995). The Gymnasium of Virtue: Education \& Culture in Ancient Sparta, University of North Carolina Press.

Lattimore, R. A. (1960). Greek lyrics, University of Chicago Press.

Ollier, F. (1933). Le mirage spartiate: étude sur l'idéalisation de Sparte dans l'antiquité grecque de l'origine jusqu'aux cyniques, E. de Boccard.

Nussbaum, M. (2002). The Incomplete Feminism of Musonius Rufus: Platonist, Stoic, and Roman. The Sleep of Reason: Erotic Experience and Sexual Ethics in Ancient Greece and Rome.

Pomeroy, S. B. (2002). Spartan Women, Oxford University Press.

Powell, A. (2002). Plato and Sparta: modes of rule and of non-rational persuasion in the Laws. The Shadow of Sparta. S. Hodkinson, A. Powell and A. Powell, Taylor \& Francis.

Thucydides (2009). The Peloponnesian War. M. Hammond and P. J. Rhodes, OUP Oxford.

West, C. and D. H. Zimmerman (1987). "Doing Gender." Gender and Society 1(2): $125-151$. 